\title{
GAMBARAN PENGGUNAAN DAN PENYIMPANAN OBAT OLEH MASYARAKAT DI KOTA BANJARMASIN TAHUN 2020
}

\section{Overview Of The Use And Storage Of Drugs By The Community In Banjarmasin, 2020}

\section{Melviani ${ }^{\text {I* }}$ \\ Onny Ziasti Fricilia ' \\ Jason Merari \\ Peranginangin ${ }^{2}$}

\section{Felix Imanuel Rachman '}

\section{Munawarah '}

'Health Faculty, Sari Mulia University, Banjarmasin City, South Borneo 70238, Indonesia

2Pharmacy Faculty, Setia Budi University, Surakarta City, Central Java 57/27, Indonesia

*email: ayubrilianydedy@gmail.com

\begin{abstract}
Abstrak
Pandemi COVID-19 telah tersebar hampir diseluruh dunia, tidak terkecuali di Banjarmasin, Kalimantan Selatan. Beberapa obat digunakan masyarakat untuk menjaga kesehatannya. Penelitian ini berguna untuk mengetahui gambaran penggunaan obat di masyarakat serta penggunaan dan penyimpanannya pada masa pandemi. Penelitian ini menggunakan rancangan penelitian observasional dengan pendekatan cross-sectional, menggunakan teknik sampling Convenience sampling dengan aplikasi google form. Survei berbasis komunitas dilakukan terhadap 101 responden yang mewakili masyarakat di Kota Banjarmasin untuk kelompok populasi umum. Hasil yang didapatkan, 2 jenis obat yang banyak oleh responden yaitu obat-obat vitamin (72,3\%) dan suplemen (27,7\%). Responden telah mengetahui cara penggunaan obat sesuai cara pemakaiannya $(83,2 \%)$ dan dalam survei menunjukkan hasil yang sangat baik dimana $(90,1 \%)$ responden mengonsumsi obat sesuai anjuran tenaga kesehatan. Sebanyak $(64.4 \%)$ responden mengetahui cara penyimpanan obat sesuai penyimpanannya dan $(90,1 \%)$ menyimpannnya dengan benar. Maka, dapat dikatakan penggunaan dan penyimpanan sangat berpenaruh terhadap mutu obat dimana saat ini yang paling digemari adalah obat-obatan vitamin dan simtomatik.
\end{abstract}

Kata Kunci:

Penggunaan Obat

Penyimpanan Obat

Banjarmasin

\section{Keywords:}

Drug Use

Drug Storage

Banjarmasin

\begin{abstract}
The COVID-19 pandemic has spread throughout the world, including in Banjarmasin, South Kalimantan. Some medicines are used by people to maintain their health. The purpose of this study was to describe the use of drugs in the community and their use and storage during a pandemic. This research method used an observational research design with a cross-sectional approach, using the convenience sampling technique with the google form application. The community based survey was conducted on 101 respondents representing the community in Banjarmasin City for the general population group. The results of the study were 2 types of drugs that were widely used by respondents, namely vitamin drugs (72.3\%) and supplements (27.7\%). Respondents already know how to use drugs according to how they are used (83.2\%) and in the survey it shows very good results where $(90.1 \%)$ of respondents take drugs as recommended by health workers. As many as (64.4\%) of respondents knew how to store medicines according to their storage and (90.1\%) store them properly. The conclusion is that the use and storage have a big impact on the quality of the drug,
\end{abstract} which currently the most popular are vitamin and symptomatic drugs..

(C) year The Authors. Published by Institute for Research and Community Services Universitas Muhammadiyah Palangkaraya. This is Open Access article under the CC-BY-SA License (http://creativecommons.org/licenses/by-sa/4.0/). DOI: https://doi.org//0.33084/jsm.vxix.xxx.

\section{PENDAHULUAN}

Pandemi adalah epidemi yang terjadi pada skala yang melintasi batas internasional, biasanya memengaruhi sejumlah besar orang. (Miquel Porta, 2008) Suatu penyakit atau kondisi bukanlah pandemi hanya karena tersebar luas atau membunuh banyak orang, penyakit atau kondisi tersebut juga harus menular. Misalnya, kanker bertanggung jawab atas banyak kematian tetapi tidak dianggap sebagai pandemi karena penyakit ini tidak menular. (Dumar A. M., 2009) Pandemi COVID19 telah tersebar hampir diseluruh dunia, tidak terkecuali di Banjarmasin, Kalimantan Selatan. Jumlah korban terinfeksi terus bertambah, pemerintah telah 
melakukan beberapa program untuk menekan jumlah penyebaran COVID-19. Meskipun demikian kondisi ini dapat terus belanjut hingga ditemukannya obat/vaksin untuk mengatasinya.

Tanda dan gejala umum infeksi COVID-19 antara lain gejala gangguan pernapasan akut seperti demam, batuk dan sesak napas. Masa inkubasi rata-rata 5-6 hari dengan masa inkubasi terpanjang 14 hari. Sementara pada kasus COVID-19 yang berat dapat menyebabkan pneumonia, sindrom pernapasan akut, gagal ginjal, dan bahkan kematian. Tanda-tanda dan gejala klinis yang dilaporkan pada sebagian besar kasus adalah demam, dengan beberapa kasus mengalami kesulitan bernapas, dan hasil rontgen menunjukkan infiltrat pneumonia luas di kedua paru.

Penggolongan obat berdasarkan jenis tertuang dalam Peraturan Mentri Kesehatan Republik Indonesia Nomor 917/Menkes/X/1993 yang kini telah diperbaharui oleh Permenkes RI Nomor 949/Menkes/Per/VI/2000 menyatakan penggolongan obat terdiri atas; obat bebas, obat ini dijual bebas di pasaran dan dapat dibeli tanpa resep dokter, tergolong yang paling aman, dapat dibeli tanpa resep di apotik dan dijual di warung-warung. Obat bebas biasanya digunakan untuk mengobati dan meringankan gejala penyakit. Obat bebas terbatas, obat yang dalam jumlah tertentu aman dikonsumsi namun jika terlalu banyak akan menimbulkan efek yang berbahaya. Obat wajib apotek, obat keras yang dapat diserahkan oleh apoteker pengelola apotek tanpa resep dokter. Obat keras, obat yang berbahaya sehingga pemakaiannya harus di bawah pengawasan dokter dan obat hanya dapat diperoleh dari apotek, puskesmas dan fasilitas pelayanan kesehatan lain seperti balai pengobatan dan klinik dengan menggunakan resep dokter. Psikotropika dan narkotika, merupakan zat atau obat yang secara alamiah ataupun buatan yang berkhasiat untuk memberikan pengaruh secara selektif pada sistem syaraf pusat dan menyebabkan perubahan pada aktivitas mental dan perilaku. Sehingga perlunya manajemen dalam penggunaan obat, dalam hal ini adalah penyimpanan agar obat tetap berada pada kondisi yang optimal sebelum digunakan oleh pasien atau masyarakat (Noval et al., 20l8).

Tujuan Penelitian ini perlu dilakukan dan dari hasil penelitian ini diharapkan dapat mengetahui data mengenai penggunaan obat dan penyimpanan obat masyarakat dengan populasi di Banjarmasin, Kalimantan Selatan. Sehingga penelitian ini dapat memberikan informasi obat-obat apa saja yang banyak digunakan masyarakat Banjarmasin di masa pandemi COVID-19 tahun 2020.

\section{METODOLOGI}

\section{Alat dan bahan}

Penelitian ini menggunakan alat dan bahan berupa kuisioner melalui Google Form dengan memperhatikan lokasi geografis masyarakat.

\section{Metode}

Penelitian ini menggunakan rancangan penelitian observasional dengan pendekatan cross-sectional. Peneliti menggunakan Teknik Cluster sampling dimana peneliti memperoleh sampel dengan membentuk beberapa cluster dari hasil penyeleksian sebagian individu yang menjadi bagian dari sebuah populasi. Teknik ini cukup mudah, murah dan tepat pada kriteria inklusi yang dituju.

Populasi yang digunakan dalam penelitian ini adalah masyarakat umum di Kota Banjarmasin. Beberapa kriteria yang diinginkan adalah masyarakat dengan kondisi yang sehat, berdomisili di Kota Banjarmasin dengan usia 18-65 tahun, subjek bersedia berpartisipasi dalam penelitian, subjek kooperatif, dapat berkomunikasi dengan baik, tingkat pendidikan yang beragam dan pendapatan yang bervariasi dari rendah, sedang dan tinggi.

Data yang digunakan meliputi data primer yang diperoleh dari google form, dengan memperhatikan lokasi geografis. Metode pemilihan sampel dilakukan dengan menentukan sampel (n) dari populasi di Kota 
Banjarmasin. Besar sampel (n) ditentukan menggunakan formula Taro Yaname. Maka minimal jumlah sebaran sampel yang diperoleh di Kota Banjarmasin sebanyak IOI sampel.

\section{HASIL DAN PEMBAHASAN}

Penelitian ini mendapatkan sebanyak IOI subjek dengan populasi umum (sehat). Subjek responden terdiri dari 44 subjek laki-laki (43,6\%) dan 57 subjek perempuan (56,4\%). Rentang usia responden berkisar antara 17-63 tahun. Pendidikan responden paling banyak merupakan 50 subjek Sarjana (49,5\%) dan 45 subjek SMA (44,6\%).

Tabel I. Persentase Pemakaian dan Penyimpanan Obat

\begin{tabular}{|c|c|c|}
\hline Permasalahhan & $\begin{array}{c}\text { Persentasi } \\
\text { (\%) }\end{array}$ & Keterangan \\
\hline $\begin{array}{c}\text { Responden } \\
\text { mengetahui cara } \\
\text { penggunaan obat }\end{array}$ & 83,2 & $\begin{array}{l}\text { Responden diminta untuk } \\
\text { mengisi kuisioner yang } \\
\text { diberikan. Hasilnya dalam hal } \\
\text { cara penggunaan obat, } 84 \\
\text { responden telah mengetahui } \\
\text { cara penggunaan obat dan I7 } \\
\text { responden belum mengetahui } \\
\text { cara penggunaan obat. }\end{array}$ \\
\hline $\begin{array}{l}\text { Kesesuaian } \\
\text { anjuran }\end{array}$ & 90,1 & $\begin{array}{l}\text { Dalam hal mengonsumsi obat, } \\
\text { responden menggunakan obat } \\
\text { sesuai anjuran tenaga medis } \\
\text { sebanyak } 91 \text { orang dan yang } \\
\text { enggan menggunakan sesuai } \\
\text { anjuran sebanyak } 10 \text { orang. }\end{array}$ \\
\hline $\begin{array}{l}\text { Mengetahui cara } \\
\text { penyimpanan obat }\end{array}$ & 90,1 & $\begin{array}{l}\text { 9I responden mengaku } \\
\text { mengetahui cara penyimpanan } \\
\text { obat menyimpan obat di } \\
\text { dalam wadah tertutup baik } \\
(69,3 \%) \text {, plastic klip (II,9\%) } \\
\text { serta di lemari es }(9,9 \%) \text { dan } \\
\text { laci/rak ( } 8,9 \%) \text {. Sedangkan } 10 \\
\text { responden } \\
\text { mengetahuinya. }\end{array}$ \\
\hline $\begin{array}{l}\text { Mengetahui cara } \\
\text { penyimpanan obat } \\
\text { dengan benar }\end{array}$ & 64 & $\begin{array}{l}\text { Dari } 91 \text { responden yang } \\
\text { mengaku tau cara menyimpan } \\
\text { obat, hanya } 58 \text { responden } \\
\text { mengetahui cara penyimpanan } \\
\text { obat dengan benar sedangkan } \\
33 \text { responden kurang tepat. }\end{array}$ \\
\hline $\begin{array}{l}\text { Penggunaan obat- } \\
\text { obatan suplemen }\end{array}$ & 72,3 & $\begin{array}{lrr}\text { Sebanyak } & 73 & \text { orang } \\
\text { menggunakan } & \text { obat-obatan } \\
\text { suplemen } & \text { dalam } & \text { masa } \\
\text { pandemi ini. } & & \end{array}$ \\
\hline $\begin{array}{l}\text { Penggunaan obat } \\
\text { simtomatik }\end{array}$ & 27,7 & $\begin{array}{lrr}\text { Sebanyak } & 28 & \text { orang } \\
\text { menggunakan } & \text { obat-obatan } \\
\text { simtimatik } & \text { dalam } & \text { masa } \\
\text { pandemi ini. } & & \end{array}$ \\
\hline
\end{tabular}

Dari data yang didapat ditemukan pada table I dapat dilihat bahwa cara penggunaan obat pada masyarakat Banjarmasin dengan data yang kami peroleh didapat bahwa (83,2\%) responden mengetahui cara penggunaan obat. Hal ini merupakan suatu yang cukup baik, jika dilihat kilas balik pada penelitian (Jefrin Sambara et.al ,2014) di Kota Kupang Tahun 2014, dari total 270 responden yang diteliti, hanya $48,52 \%$ tahu dan paham tentang cara penggunaan obat yang benar sedangkan $5 \mathrm{I}, 48 \%$ tidak tahu dan tidak paham tentang cara penggunaan obat yang benar. Hasil yang baik juga didapatkan dari penelitian (Hening Pratiwi,2016) pada penduduk Desa Kutasari Baturaden Purwokerto. Setelah dilakukannya edukasi, (I00\%) responden telah mengetahui cara penggunaan obat yang sesuai. Hal ini menunjukkan pentingnya edukasi untuk meningkatkan pemahaman masyarakat.

Cara responden mengomsumsi obat dalam survei kami menunjukkan hasil yang sangat baik dimana $(90,1 \%)$ responden mengonsumsi obat sesuai anjuran, jika dibandingkan dengan penelitian lampau distribusi frekuensi pengetahuan dari penelitian (Ertati Suarni et al,20I3) di Apotek Kecamatan Ilir Barat I Kota Palembang yang hanya $(52,2 \%)$ yang mengonsumsi obat sesuai anjuran dari keseluruhan responden. Hasil yang baik didapatkan dari penelitian (Hening Pratiwi,2016) pada penduduk Desa Kutasari Baturaden Purwokerto. Setelah dilakukannya edukasi, (I00\%) responden telah menggunakan obat sesuai dengan anjuran yang diberikan. Hal ini menunjukkan pentingnya edukasi untuk meningkatkan pemahaman masyarakat.

Tempat penyimpanan obat dari penelitian (Julia Salsabila,2018) terdapat 3 tempat yang sering digunakan sebagai tempat penyimpanan yaitu kulkas (26,6\%), lemari (25,5\%), dapur/meja makan $(21,8 \%)$, jika dibanding dengan penelitian kami, responden paling banyak menyimpan obat di dalam wadah tertutup baik (69,3\%), plastic klip (1I,9\%) serta di lemari es $(9,9 \%)$ dan laci/rak (8,9\%). Penyimpanan obat pada wadah tertutup baik sudah baik, sesuai dengan bentuk 
sediaanya dimana yang terbanyak merupakan bentuk tablet (76,2\%). Penelitian (Fitsum Sebsibe Teni, 20I7) pada masyarakat di kota gondar, Northwestern Ethiopia. ditemukan data tempat penyimpanan obat adalah $(76,5 \%)$ di laci lemari, $(5,2 \%)$ di kulkas, $(5,4 \%)$ di tas, (4\%) kantung baju. Hal ini juga sesuai dengan jenis sediaannya dimana paling banyak adalah berbentuk solid. Pada penelitian (Hening Pratiwi,2016) pada penduduk Desa Kutasari Baturaden Purwokerto. Setelah dilakukannya edukasi (7I\%) responden telah mengetahui cara penyimpanan obat dengan benar.

Dari data yang didapat ditemukan pada table I dapat dilihat bahwa penggunaan obat terbanyak (72.3\%) selama pandemi adalah obat obatan suplemen berupa vitamin $\mathrm{C}$ yang digunakan untuk meningkatkan imunitas tubuh melawna patogen. Vitamin adalah zat atau senyawa organik kompleks yang biasa ditemukan dalam makanan yang berfungsi mengatur proses metabolisme tertentu di dalam tubuh kita. Suplemen adalah produk kesehatan yang mengandung satu atau lebih zat yang bersifat nutrisi atau obat yang dikemas dalam bentuk kapsul, kapsul lunak, tablet, bubuk atau cairan yang berfungsi sebagai pelengkap kekurangan zat gizi dalam tubuh (Vitahealth 2004 dan McDowall 2007). Vitamin $C$ adalah nutrisi penting yang terlibat dalam beragam fungsi kekebalan; suplementasinya telah menunjukkan efek menguntungkan pada berbagai jenis infeksi virus (Colunga Biancatelli RML et al,2020). Pada beberapa kasus infeksi virus ditemukan adanya penurunan pada vitamin C plasma pada pasien. (Chen JY et al,2009) Hal ini berarti, Vitamin $C$ merupakan zat yang esensial unruk tubuh guna melawan infeksi dari patogen.

Berdasarkan keputusan kepala BPOM nomor HK.00.05.3.02706 tahun 2002 bab 2 tentang promosi obat jadi, menyatakan bahwa obat bebas dan obat bebas terbatas dapat dipromosikan. Promosi ini dalam pasal 5 menyakakan dapat melalui media audio visual, dan elektronik. Sejalan dengan peraturan diatas, berdasarkan peraturan kepala BPOM RI No.8 tahun 2017 tentang pedoman pengawasan periklanan obat,

dalam bab 3 pasal 3 ayat 3 menyatakan periklanan obat bebas dan obat bebas terbatas dapat dilakukan melalui media cetak, media elektronik, dan media luar ruang. Berdasarkan pasal 4 ayat I media cetak yang dimaksud adalah: surat kabar, majalah, tabloid, buletin, kalender, poster/selebaran, leaflet, stiker, buklet, pamflet, yellow pages.

Berdasarkan pasal 4 ayat 2 media elektronik yang dimaksud adalah: televisi (termasuk iklan baris/running text), dan radio. Berdasarkan pasal 4 ayat 3 media luar ruangan yang dimaksud adalah: papan reklame, pillboard, lampu hias/neon box, papan nama, balon udara, sarung ban mobil, iklan cetak yang ditempel/digantung di luar ruangan, spanduk, transit ad (iklan yang diletakkan pada objek bergerak), videotron, gimmick, backdrop. Mengingat banyaknya sarana untuk mempromosikan obat bebas ini maka, masyarakat luas dapat mengetahui tentang penggunaan obat suplemen dan vitamin serta obat-obatan simtomatik sehingga penjualannya dapat meroket naik melebihi obat-obatan jenis lain.

Pada Tabel I didapati pula obat-obatan yang banyak digunakan kedua adalah obat simtomatik seprti analgetik, antipiretik, antitusif, dekongestan, dan antialergi. Dari hasil yang didapatkan obat obatan suplemen merupakan obat dengan penggunaan paling banyak yang digunakan selama masa pandemi di Banjarmasin, diikuti oleh obat obat simtomatik. Sejalan dengan hasil penelitian ini, berdasarkan pedoman pencegahan dan pengendalian coronavirus disease (COVID-19) per 27 maret 2020 dinyatakan bahwa salah satu upaya unruk meningkatkan imunitas diri salah satunya adalah mengonsumsi suplemen vitamin. Dengan hasil yang didapat maka dapat dilihat bahwa masyarakat telah mematuhi dan mengerti anjuran dari pemerintah atau dinas Kesehatan untuk mengonsumsi suplemen vitamin.

\section{KESIMPULAN}


Dari hasil penelitian ini didapatkan sebagian besar masyarakat Banjarmasin telah mengetahui cara untuk mengelola obat dan gambaran obat-obat yang dikonsumsi seperti vitamin $\mathbf{( 7 2 , 3 \% )}$ dan suplemen $(27,7 \%)$ yang menjadi primadona dimasa pandemi ini. Hal ini berdampak akibat dari edukasi kesehatan yang membangun kesadaran masyarakat untuk mencegah terpaparnya COVID-19 dan juga pengetahuan masyarakat untuk pengelolaan obatnya masing-masing.

\section{UCAPAN TERIMA KASIH}

Ucapan terima kasih disampaikan kepada semua pihak, termasuk mitra kerjasama yang baik secara langsung maupun tidak langsung telah menumbuhkan ide atau gagasan serta membantu jalannya proses dalam menyelesaikan penelitian ini.

\section{REFERENSI}

I. Miquel Porta. 2008. Miquel Porta, ed. Dictionary of Epidemiology. Oxford University Press. hlm. 179. ISBN 978-0-19-53I449-6 Samrin. 2016. Pendidikan Karakter (Sebuah Pendekatan Nilai). Jurnal Al-Ta'dib. 9(I): I20-|43.

2. A. M., Dumar. 2009. Swine Flu: What You Need to Know. Wildside Press LLC. hlm. 7. ISBN $978 \mid 434458322$.

3. Peraturan Menteri Kesehatan Republik Indonesia Nomor: 949/MENKES/PER/VI/2000 Tentang Registrasi Obat Jadi.

4. Keputusan Kepala Badan Pengawas Obat Dan Makanan Nomor Hk.00.05.3.02706 Tahun 2002 Tentang Promosi Obat.

5. Peraturan Kepala Badan Pengawas Obat Dan Makanan Republik Indonesia Nomor 8 Tahun 2017 Tentang Pedoman Pengawasan Periklanan Obat

6. Noval, N., Oetari, R. A., Widodo, G. P. (20l6). Strategi Pengembangan Instalasi Farmasi Berbasis Evaluasi Akreditasi Manajemen Penggunaan Obat (Mpo) Rumah Sakit. JURNAL MANAJEMEN DAN PELAYANAN FARMASI (Journal of Management and Pharmacy Practice), 6(3), 169-176. https://doi.org//0.22146/jmpf.344
7. Sambara Jefrin,Dkk. 20I4. Tingkat Pengetahuan Dan Pemahaman Masyarakat Tentang Penggunaan Obat Yang Benar Di Kota Kupang Tahun 2014. POLTEKESKupang: Kupang.

8. Pratiwi Hening Dkk. 2016. Pengaruh Edukasi Terhadap Pengetahuan, Sikap, Dan Kemampuan Berkomunikasi Atas Informasi Obat. Farmasi, Universitas Jenderal Soedirman:Purwokerto.

9. Suarni Ertati, Dkk. 2013. Hubungan Pengetahuan dan Sikap terhadap Perilaku Konsumsi Obat Tanpa Resep Dokter di Apotek Kecamatan Ilir Barat I Kota Palembang Tahun 2013. Fakultas Kedokteran Universitas Muhammadiyah: Palembang.

10. Salsabila Julia. 2018. Gambaran Penyimpanan Obat di Rumah pada Masyarakat di RW 05 Kelurahan Periuk Jaya Tangerang periode Februari-April 2018. POLTEKES KEMENKES: Jakarta.

II. Teni, Fitsum, et al. 2017. A household survey of medicine storage practices in Gondar town, northwestern Ethiopia. Public Health

12. Vitahealth. 2004. Seluk Beluk Food Supplement. PT. Gramedia Pustaka Utama. Jakarta

13. McDowall, Jill Anne. 2007. Supplement Use by Young Athletes. Journal of Sport and Medicine 6;37-342.

14. Colunga Biancatelli RML, Berrill M, Catravas JD, Marik PE. Quercetin and Vitamin C: An Experimental, Synergistic Therapy for the Prevention and Treatment of SARS-CoV-2 Related Disease (COVID-19). Front Immunol. 2020;II:|45I. Published 2020 Jun 19. doi:I0.3389/fimmu.2020.0I45.

15. Chen JY, Chang CY, Feng PH, Chu CC, So EC, Hu ML. Plasma vitamin $C$ is lower in postherpetic neuralgia patients and administration of vitamin $C$ reduces spontaneous pain but not brush-evoked pain. Clin J Pain. 2009;25(7):562-569. doi:10.1097/AJP.0b013e318193cf32.

16. Pedoman Pencegahan Dan Pengendalian Coronavirus Disease (COVID-19) per 27 maret 2020 